\title{
Implications of Organizational Culture and Leadership Styles The Effects on Job Satisfaction and Organizational Performance Of Police Sector In Bandung, Cimahi, Garut- West Java.
}

\author{
Aripin $^{1}$, Ubud Salim ${ }^{2}$, Margono Setiawan ${ }^{3}$, Djumahir $^{4}$ \\ ${ }_{1,2,3,4}$ Doctorate Program of Management Sciences - Faculty of Economics and Business - University Brawijaya, \\ Malang, East Java, Indonesia
}

\begin{abstract}
Police Sectors in Bandung, Cimahi and Garut are considered that they are not able to give the best performance yet, where the crime tends to upset the society. Furthermore, the perpetrators of several criminal cases cannot be revealed yet. The aims of this study are to measure and analyze the extent to which the police organizations performance are influenced by organizational culture, leadership style and job satisfaction. This study used a quantitative approach with path analysis as its method where 167 policemen were used as its samples. The research findings show that organizational culture significantly affected towards the job satisfaction, but insignificantly affected the organizational performance. Leadership style significantly affected job satisfaction, but insignificantly affected the organizational performance. Job satisfaction worked as a mediator of the effect between the relationship of organizational culture and organizational performance, and between the relationship of leadership style and organizational performance.
\end{abstract}

Keywords: Organizational Culture, Leadership Style, Job Satisfaction and Organizational Performance.

\section{Introduction}

Employee's performance is expected to be beneficial to the organizational performance because it's the synergy of the entire employee performance (1). Employee's performance reflects the overall organizational performance (2). McClelland (3) explained that the values, trust and ideology are important resources for the employee's achievement to perform well. Chang and Lee (4) stated that the performance of the employees is affected by the prevailing culture in the organization where the person worked.

Peters and Waterman (5) also stated superior performance is not only determined by the organizational culture, but also the leadership style. Strong organizational culture is a culture that can create the level of employee behavior that supports the structure and outstanding self-control in helping the organizational performance (6). The study of organizational culture associated with job satisfaction is very diverse. Some claimed cultural organizations can improve employee's job satisfaction (7), (8). There are others who mentioned organizational culture has no relationship to job satisfaction (9). Others said organizational culture affects the job satisfaction indirectly because it is mediated by an adequate reward (10). The study of leadership styles associated with employee's performance also varied. It is said that the leadership style has been able to influence their employees by increasing job satisfaction (11), (12), (13), (14), (15), (16), (17). However, the results of another study stated there was no link between leadership style and organizational performance (18). Therefore, research that links organizational culture, leadership style, and job satisfaction with the organizational performance has both theoretical and empirical foundations.

One of the organizational performances required to provide community service is the Police organization. The Police credibility is continuously highlighted and expected to perform well. Sector Police Performance faces a big challenge, so that it must build a culture that is appropriate for the vision and mission of organization (19). Some issues about the Sector Police performance in Bandung, Cimahi and Garut are: 1) The Police members often come late to the crime scene; 2) There are some Police members who have inadequate skills in securing and processing the crime scene, 3) The completion of criminal cases and traffic are often late. 4) The patrol practice is only done in the city. 5) The completion level of the case is still low.

The main objective of this study is to analyze and assess how the performance of the sector police organization in Bandung, Cimahi and Garut can work well when connected to organizational culture, leadership style and job satisfaction.

\section{Literature Review}

Issues which become the influence of relationship between organizational culture and leadership style on the employee's performance that is intervened by job satisfaction can be explained by two factors motivation approach of Herzberg theory (1966) and Porter and Lawler theory of motivation (1968). Herzberg (20) explained that there were two factors which motivated employees. The factors were driving force that arose 
from each employee and the driving force that came from outside of the employee where they worked (21). Porter and Lawler (22) stated that employee's performance would increase when employees felt justice and extrinsic rewards (salary and promotion) and intrinsic rewards (sense of what has been achieved). This condition would lead to a high level of satisfaction. Lawler and Porter (23) also stated that job satisfaction affected employee's performance.

\section{A. Organizational Culture}

Organizational culture is based on the concept of building on three levels: Level Basic Assumption, Value, and Artifact namely something that is left behind. A level of basic assumptions is a human relationship with what is in the environment; such as nature, plants, animals, and other humans. The basic assumption could mean a philosophy, a belief that cannot be seen by the eye but it is existed. Second, Value has a deep relation to acts or behavior. Because of it, value can be measured with any changes or through social consensus. While the artifact is something that can be seen but it is difficult to simulated. It can be in the form of technology, art, or anything that can be heard (24).

Organizational culture is a form of beliefs, values, and ways that can be learnt to cope and live in organization. Organizational culture is likely to be realized by the organization members (25). Deal and Kennedy (26) stated that a strong culture would drive the organization performance and served to overcome the organizational members' problems to adapt to their external environment by strengthen the understanding of the organization members, the ability to realize the mission, goals, method, standard, and evaluation.

\section{B. Leadership style.}

A leader has a role of determining activity programs based on the organizational basic assumptions, or management concepts that are used as Six Sigma. If the behavior of subordinates is in accordance with the program outlined by the leader, the value obtained is high, and vice versa when the behavior of individuals within the organization is far from the truth as stated in the program of work by the leader, then the value is low (27).

The interaction between leaders and employees is characterized by the influence of the leader to change the employee's behavior to be someone who is capable and highly motivated and tries to achieve a high work performance and quality. Leaders change the employees so that organizational goals can be achieved together. The aspects of transformational leadership are: charismatic, inspirational, intellectual stimulation, and individual attention (28). Gibson, Ivancevich, and Donnelley (29) mentioned that leadership was an effort of influence, rather than a force to motivate people to achieve certain goals. In other words, a leader is someone who has the power to attract others with no compulsion so that they can actualize their vision together.

\section{Job Satisfaction}

Howell and Dipboye (30) stated that job satisfaction was the overall result of the employee's like and dislike degree on various aspects of the job. This showed that job satisfaction reflected a person's attitude toward his work, which would affect the performance of one's work. Weiss et al. (31) expressed job satisfaction as a basic indicator of individual success in the workplace which had been achieved in maintaining a relationship between himself and the work environment; consisting of intrinsic and extrinsic satisfaction.

Luthans (1995) said that job satisfaction was an expression of employee's satisfaction about how their work could give benefit to the organization, which means that what was obtained in the works had already met things that were considered important (32)

Job satisfaction is expressed as something fun or the positive emotional outcome for submitting one's or work experience (33). The relationship between subordinate and the leaders is very important in improving the productivity of the work which can be improved through attention and good relationship of leaders to subordinates, so that employees will feel that they are an essential part of the organization they work (34).

\section{Organizational Performance.}

Performance — often referred to performance — is also called the result which means what the individual employee has produced. Result is affected by the organizational performance whose components consist of Organizational Development, Compensation Plan, Communication System, Managerial Style, Organization Structure, Policies and Procedures (35). Another term is human output which can be measured from the productivity, absence, turnover, citizenship, and satisfaction (36). Individual performance is also called job performance, work outcomes, and task performance (37) 


\section{Methods}

\section{Research Design}

This research was designed through explanations (explanatory research) by applying survey methods. It was specifically examined the phenomenon and results of empirical studies related to the improvement of organizational performance in the Sector Police in three cities in West Java, Indonesia - Bandung, Cimahi, and Garut. The quantitative research was used to get an overview and profound explanations of the phenomenon and the results of empirical studies related to problems in the research.

\section{Data Analysis Techniques}

This research used a path analysis technique. There were 70 Sector Police Offices in Bandung, Garut, and Cimahi used as the research population. The number of samples was represented by 288 Sector Police members as respondent with the Slovin formula (38) to obtain a total sample of 167 respondents. The indicator and item of research were based on organizational culture, leadership style, job satisfaction, and organizational performance variables which were applied in the research instrument. Then it was distributed to 167 respondents.

In order to check the reliability and validity of the research, the research instrument was tested to 30 respondents in a try out before it was distributed. The try out result had fulfilled the requirements to proceed with the research.

\section{Results}

This chapter shows an overview of the respondent descriptions; among them are gender, age, the level of general education, rank and work experience. All of them are summarized and presented in the following table.

\section{A. Description of Respondents.}

Table1. Respondent Description

\begin{tabular}{|l|l|c|c|}
\hline & \multicolumn{1}{|c|}{ commentary } & Total & Percentage \\
\hline 1. & Male & 167 & $100 \%$ \\
2. & Female & - & - \\
\hline & Total & 167 & $100 \%$ \\
\hline & Age of Respondents & 31 & \\
1. & Less than 30 years & 46 & 18,56 \\
2. & More than 30 years - 40 years & 79 & 27.54 \\
3 & More than 40 years -50 years & 10 & 47.31 \\
4 & More than 50 years & 167 & 6.59 \\
\hline & Total & & $100 \%$ \\
\hline & Education Level & 51 & \\
1. & Junior High School & 82 & 31,14 \\
2. & Senior High School & 23 & 49,70 \\
3 & University & 167 & 13,77 \\
\hline & Total & & $100 \%$ \\
\hline & Stratification according to rank & 55 & \\
1. & Enlisted (Corporal of Police) & 69 & 36,55 \\
2. & Petty officer (Brigadier of Police) & 42 & 38.38 \\
3 & Officer (Inspector of Police) & 167 & 25,07 \\
\hline & Total & & $100 \%$ \\
\hline & Respondents experience & 44 & \\
1. & Less than 10 years & 53 & 26,35 \\
2. & More than 10 years - 15 years & 46 & 31,74 \\
3 & More than 15 years - 20 years & 23 & 27,54 \\
4 & More than 20 years & 167 & 14,37 \\
\hline & Total & & $100 \%$ \\
\hline
\end{tabular}

According to Table 1, all respondents are male (100\%). All member who served in the Sector Police are men because the areas of duty are rather wide and through villages, so it requires a strong physical. In terms of age, the members are generally dominated by the older age in 40-50 age range (79 respondents). This age range is the productive age and has extensive experience that supports the younger ones. The education level is generally dominated by the senior high school ( 82 respondents) because mostly the members were Senior High 
School graduate when they entered Police Force. In general, the members rank are non-commissioned officer (69 respondents) with a work experience ranging from 10 years to 15 years.

\section{B. Hypothesis testing results}

Table 2. Direct Effect between Variables

\begin{tabular}{|l|l|c|c|l|}
\hline \multicolumn{1}{|c|}{ Independent variables } & \multicolumn{1}{|c|}{ Dependent variable } & coefficient & $\mathrm{p}$-value & \multicolumn{1}{|c|}{ information } \\
\hline Organizational Culture & Job Satisfaction & 0,754 & 0,000 & Significant \\
\hline Leadership Style & Job Satisfaction & 0,230 & 0,003 & Significant \\
\hline Organizational Culture & Organizational performance & 0,000 & 0,999 & not Significant \\
\hline Leadership Style & Organizational performance & 0,000 & 0,990 & not Significant \\
\hline Job Satisfaction & Organizational performance & 0,891 & 0.000 & Significant \\
\hline
\end{tabular}

Table 3 Indirect Effect between Variables

\begin{tabular}{|c|l|c|c|}
\hline No & \multicolumn{1}{|c|}{ Effect of variable } & Magnitude Effects & Information \\
\hline 1 & $\begin{array}{l}\text { Organizational Culture on Organizational } \\
\text { Performance through Job Satisfaction }\end{array}$ & 0,754 X $0,891=0,672$ & Significant \\
\hline 2 & $\begin{array}{l}\text { Leadership Styles on Organizational Performance } \\
\text { through Job Satisfaction }\end{array}$ & 0,230 X 0,891 = 0,205 & Significant \\
\hline
\end{tabular}

According to the tables above, it can be explained that:

1. Organizational Culture directly had significant positive effect on job satisfaction.

2. Leadership style directly had significant positive effect on job satisfaction.

3. Job satisfaction directly had significant positive effect on organizational performance.

4. Organizational Culture had no significant effect on organizational performance. Job satisfaction was a mediator of the relationship between organizatonal culture and job performance.

5. Leadership Style had no significant effect on organizational performance. Job satisfaction was a mediator of the relationship between leadership style and organizational performance.

\section{Analysis And Discussion}

Organizational Culture Sector Police in Bandung, Cimahi and Garut had been able to increase job satisfaction. This means that the prevailing culture has fulfilled the expectations of its members. The results of this study support the research conducted by Kirk L. Rongga (2001); Chow, et al. (2001). Although cultural objects and sites, as well as measuring instruments used are different, but the same results, so it can be said of this study extend the results of previous studies.

The leadership style adopted by Chief of Sector Police has been trying to increase the member's job satisfaction. This means that the leadership had tried to provide a broad autonomy for the development of insight members and to encourage members to work better.

The research results support the study done by Chan et al (2004), Wilson (1995), Savery (2001); Chew and Sharma (2005). It indicates that the leadership styles used by a manager could be accepted by employees. The increase of job satisfaction which could increase the job performance indicated that job satisfaction was an important matter and it was formed from the autonomy of the supervisor, as well as feedback from colleagues. These results also supported previous research conducted by Lawler and Porter (1967) which concluded that high job satisfaction would improve the performance of the company.

Organizational culture has not been able increase the organizational performance to the fullest yet. This means that the value of organizational culture from management support indicators had not been able to improve organizational performance related to the criminal disclosure cases that accumulated due to limited funding and human resource competencies. The results of the study supported the research conducted by Gifford, Zammuto and Goodman (2002) which indicated that good performance was not only influenced by culture, but there were also other variables affected good performance. One of them was job satisfaction. Factors of organizational culture at the moment were faced with a change from military culture to civilian culture. The culture transition made the existing organizational culture under a less powerful condition, so that it could give an impact on organizational performance .

Job satisfaction was a mediator of the power of organizational culture in improving the organizational performance, which means the member's job satisfaction had an important role to strengthen the organization culture to result in organizational performance. This study collaborated with Hesberg theory (1968) on Job Satisfaction

Leadership style is not maximal yet in improving the organizational performance. This means that the leadership style would be able to improve organizational performance if it could increase member's satisfaction. This is understandable because the leadership was still in a transition from military culture to civilian culture. 
Military culture tended to impose the will of its members to work optimally although the operational management support was inadequate. The results of this study are not the same as the results of research conducted by Nicholas O' Regan and Abby Ghobadian (2004), Shao Lian, Sheila Webber, (2004), Montes, (2005), Alberto, Aragon (2007).

However, the results of this study support the research conducted by Ogbonna and Harris (2000). Job satisfaction was a mediator of the influence of leadership style on the organizational performance, which means that member's job satisfaction was determined by the role of leadership style in order to improve organizational performance. This reseach can be collaborated with Schein (1991) on leadership styles.

\section{Conclusion}

Organizational culture wass formed from the management support, work challenge, loyalty, social cohesion and community cooperation. Leadership style which was formed from the charismatic leadership style, inspirational, intellectual stimulation, and individual attention had been able to increase the job satisfaction of its members. Job satisfaction which was formed through autonomy and feedback could improve organizational performance. On the other hand, organizational culture that had been formed from the management support, work challenge, loyalty, social cohesion and community cooperation could not improve organizational performance.

Therefore, it can be proved that the existence of the phenomenon that the sector Police performance of Bandung, Cimahi and Garut assessed was not maximal to the public yet. Similarly, the leadership style of Sector Police leader formed from high charisma, inspirational, intellectual stimulation, and individual attention had not been able to improve the Sector Police organizational performance because of the transition in leadership culture. Due to thelimited financial support operations, Sector Police leader's concern for each individual had not laid out well in working up the tasks of prevention implementation, prosecution and protection

Finally, to make organizational culture and leadership style in police Bandung, Cimahi and Garut perform well, the job satisfaction factor becomes an important factor to support a stronger organizational culture and leadership style in accordance with the members' expectations, so that the organizational performance becomes better in fulfilling the community's expectation.

[1] Eoh. "The Influence of Corporate Culture, Management Style, and Employee Performance against Team Development: A Case Study in PT Semen Gresik and PT. Semen Kujang”. Diss., Universitas Indonesia. 2001.

[2] Chew, Irene. K. H., and B. Sharma. "The effect of Culture and HRM practices on firm performance Empirical evidence from Singapore". International Journal of Manpower Vol. 26 (6) (2005): 560-58.

[3] McClelland, D. C. The Achieving Society. Princeton, NJ: Van Nostrand, 1961.

[4] Chang, S.C., and M.S. Lee. "A Study on Relationship among Leadership Organizational Culture, the Operation of Learning Organization and Employees Job Satisfaction". Journal of the Learning Organization Vol. 14 (2) (2007): 155-185.

[5] Peter, T. J., and R. H. Waterman. In Research of Excellence: Lessons from America's best-run Companies. New York: Harper and Row, 1982.

[6] Chatman, Jennifer and Bersade. "Employee Satisfaction, Factor Associated With Company Performance". Journal of Applied Psychology 29 February 1997.

[7] Rongga, Kirk L. "Human Resources Practices, Organizational Climate and Employee Satisfaction". Academy of Management Review July 2001: 619-644.

[8] Chow C.W, L. M. Jill and Anne W. Organizational Culture; association with affective Commitment, Job Satisfaction. Propensity to Remain and Information Sharing in a Chinese Culture Context. San Diego University, 2001.

[9] Gifford, B. D., R. F. Zammuto, and E. A. Goodman. "The Relationship between Hospital Unit Culture and Nurses Quality Of Life". Journal of Healthcare Management 47 (2002): 13-26.

[10] Sarros, James C., Judy H. Gray, and Iaian L. Densten. "Leadership and its Impact on Organizational Culture". International Journal of Business Studios Vol. 10 (2) (2002): 1-26.

[11] Chan, Yee-Ching Lilian. "Performance Measures and Adoption of Balanced Scorecard: a Survey of Municipal Governments in the USA and Canada". The International Journal of Public Sector Management Vol.17 (3) (2004): 204-221.

[12] Wilson, AP. "The Effects of Politics and Power onThe Organizational Commitment of Federal Executives". Journal of Management 21 (1) (1995): 101-118.

[13] Savery, L.K and J. A. Luks. "The Relationship between Empowerment, Job Satisfaction, and Reported Stress Levels : Some Australian Evidence". Leadership and Organization Development Journal 22 (2001): 97-105

[14] O'Regan, Nicholas and Abby Ghobadian. "The link between leadership, strategy, and performance in manufacture SMEs". Journal of Small Business Strategy 15 (2) (2004): 45-

[15] Lian, S., and W. Sheila. "Across-cultural test of the 'five-factor model of personality and transformational leadership". Journal of Business Research 59 (2006): 936-944.

[16] Montes, J.L., A.R. Moreno, and V.G. Morales. "Influence of Support Leadership and Teamwork Cohesion on Organizational Learning, Innovation and Performance: An Empirical Examination”. Technovation 25 (10): 1159-1172.

[17] Alberto Aragon-Correa, Victor J. Garcia-Morales, and Eulogio Cordon-Pozo. "Leadership and organizational learning's role on innovation and performance: Lessons from Spain”. Industrial Marketing Management Vol. 36 (3) April 2007: 349-359.

[18] Ogbonna, Emmanuel and Lloyd C. Harris. "Leadership Style, Organizational Culture and Performance: Empirical Evidence From UK Companies". International Journal of Human Resource Management 11, 4 August 2000: 766-788.

[19] Berry, Leonard L., David R. Bennet, and Carter W Brown. Service Quality; A Profit Strategy for Financial Institution. Home Wood, Illinois: Dow Jones Irwin, 1988.

[20] Herzberg. "The Motivation-Hygiene Theory”. Work and the Nature of Man. Cleveland, OH: World Publishing Company, 1966. 
[21] Porter, L.W. and E.E. Lawler III. Managerial Attitudes and Performance. Homewood, Illinois: Richard D. Irwin, Inc., 1968.

[22] Lawler, E. E. and L.W. Porter. "The Effect of Performance on Job Satisfaction.” Industrial Relations Vol. 7 (1968): $20-28$.

[23] Schein, E.H. Organizational Culture and Leadership. San Francisco: Joersey Bass Publishers, 1991.

[24] Brown, A. Organizational Culture. Singapore: Prentice Hall, 1998.

[25] Deal, T. and A. Kennedy. Corporate cultures: The rites and rituals of corporate life. Reading, MA: Addison-Wesley, 1984.

[26] Erwin, Jane and PC. Douglas. "It's not difficult to change company culture". Proquest, UMI, CD-ROM: Business Journal (1996).

[27] Bass, B.M. and B.J. Avolio. Improving Organizational Effectiveness through Transformational Leadership. Sage: Thousand Oaks, 1994.

[28] Gibson J. H., J. M. Ivancevich, and J. H. Donnally Jr. Organization: Behavior, Structure, Processes. Homeword, Illinois: Richard D. Irwin, Inc., 1991.

[29] Dipboye, R.L., L.S. Smith, and W.C. Howell. Understanding an Industrial and Integrated Organizational Approach Psychology. Michigan: Harcourt Brace International Editions, 1994.

[30] Weiss, D.J, et. al. Manual for the Minnesota Satisfaction Questionnaire. Minnesota: University of Minnesota, 1967.

[31] Luthans. Organizational Behavior. $7^{\text {th }}$ ed. New York: McGraw-Hill, 1995.

[32] Locke E. A. "Job Satisfaction and Job Performance: a Theoretical Analysis". Organization Behavior and Human Performance Vol. 5 (1970): 484-500

[33] Celluci, Anthony J. and David L. DeVries, "Measuring Managerial Satisfaction: A Manual for the M.J". SQ Technical Report II: Center for Creative Leadership, 1978.

[34] Cash, W.H. and F.E. Fischer. "Human Resource Planning" in Famularo, J.J.,Hand Book of Human Resources Administration. Singapore: Fong and Sons Printers Pte Ltd., 1987.

[35] Robbins, S.P. Organizational Behavior. $10^{\text {th }}$ ed., Singapore: Prentice Hall, 2003.

[36] Baron, R. A. and J. Greenberg. Behavior in Organization: Understanding and Managing the Human Side of Work, $3^{\text {rd }}$ ed. Toronto: Allyn and Bacon, 1990.

[37] Umar, H. Method Riset Bisnis. Jakarta: Gramedia Pustaka Utama, 2002. 